\title{
Profiles in Science for Science Librarians: Ruth Hubbard, Scientist and Social Activist
}

\section{Citation}

Barr, Dorothy. 2017. "Profiles in Science for Science Librarians: Ruth Hubbard, Scientist and Social Activist." Science \& Technology Libraries 37 (1) (December 13): 63-70. doi:10.1080/0194262x.2017.1395722.

\section{Published Version}

10.1080/0194262X.2017.1395722

\section{Permanent link}

http://nrs.harvard.edu/urn-3:HUL.InstRepos:41017646

\section{Terms of Use}

This article was downloaded from Harvard University's DASH repository, and is made available under the terms and conditions applicable to Other Posted Material, as set forth at http:// nrs.harvard.edu/urn-3:HUL.InstRepos:dash.current.terms-of-use\#LAA

\section{Share Your Story}

The Harvard community has made this article openly available.

Please share how this access benefits you. Submit a story.

\section{Accessibility}




\title{
Profiles in Science for Science Librarians:
}

\section{Ruth Hubbard, Scientist and Social Activist}

\author{
Dorothy Barr \\ Research Librarian \\ Ernst Mayr Library - Museum of Comparative Zoology \\ 26 Oxford Street \\ Cambridge MA 02138 \\ orcid.org/0000-0002-1958-3715 \\ dbarr@oeb.harvard.edu
}

This is an Accepted Manuscript of an article published by Taylor \& Francis in Science \& Technology Libraries on 10 December 2017 and available online: https://doi-org.ezpprod1.hul.harvard.edu/10.1080/0194262X.2017.1395722.

\begin{abstract}
Ruth Hubbard (1924-2016) is known for her groundbreaking research on the biochemistry and photochemistry of the eye and for her social activism. In 1974 she was the first woman to be tenured in biology at Harvard. In addition to her groundbreaking scientific achievements, Hubbard was motivated and influenced by the Vietnam War and the feminist movement, and began to turn her attention to social and political issues. She became an outspoken opponent of any notion of the biological inferiority of women, and also worked to promote the socially and politically responsible practice of science. This article explores Hubbard's scientific and civic work.
\end{abstract}

\section{Early Life and Education}

Among the families fleeing Vienna when the Nazis entered Austria in1938 were Richard and Helene Erlich Hoffmann, physicians and leftist intellectuals, and their children, including 14 year old Ruth (Gillinov 2016). Helene Hoffmann, in addition to her medical practice, was a concert quality pianist, and Ruth herself had given recitals before the arrival of the Nazis. The family 
settled in Brookline, Massachusetts, where her father reestablished his medical practice. Ruth found the adjustment to the U.S. difficult. She later remarked that she became "somewhat withdrawn and self-reliant. To look to [herself] for resources" (Drexler 1990, p. 74).

After high school Ruth attended Radcliffe College in Cambridge MA, which was founded in 1879 to provide higher education to women because at the time they were not admitted to Harvard. The two colleges did not officially merge until 1999, although in 1946 most classes at Harvard became coeducational. Harvard professors had always taught some classes at Radcliffe, however (https://college.harvard.edu/about/mission-and-vision/radcliffe). At first, Ruth planned to go into medicine "because everyone around me was a doctor" (Holloway 1995, p. 49). She then considered philosophy and physics but changed her mind after taking a physics class in which there were 350 men and just one other woman, so she ended up studying biochemical sciences. Much later, she commented that if someone had asked her at the time why there were so few women in physics class, she probably "would have said because they were not good enough" (Holloway 1995, p. 49). It appears that early in her career she had not given any thought to the issue of women's struggles for recognition in the sciences.

Ruth completed her A.B. at Radcliffe in 1944. Meantime, in 1942 she had married Harvard senior Frank Hubbard, just before he left for the army. She joined her husband at times from 1945 to 1946 when he was posted in Tennessee, where he was working as a laboratory technician. While there she became active in an anti-segregation group, and in her oral history in 1981, she recalled that in the South she "encountered this sense of what's going to happen when the Negros come back having learnt to shoot at white men and sleep with white women. That's how it was phrased" (Walzer 1981, p. 53). Clearly she had a strong sense of social justice even then, which is not surprising given that her parents had been activists in Austria. 
Although the Hubbards shared an interest in music and traveled together in post-World War II Europe while Frank researched historical harpsichords (see http://www.hubharp.com/about.htm\#history), the two divorced amicably in 1951.

\section{Scientific Work}

From 1944 to 1945 Ruth Hubbard was a research assistant in the Harvard biology lab of the well-known professor George Wald. They were working on infrared vision to support the Allied war effort (Griffin, Hubbard and Wald 1947). In 1946, she returned to Wald's lab to work on her Ph.D., which she received from Radcliffe in biochemistry in 1950. Wald described her as "the best graduate student [he] ever had" (Benderly 2016, para. 8). The work of Wald's lab was focused on the role of vitamin A in vision. Although the connection between diet and vision had been known as far back as ancient Egypt, no one knew what that connection was until the discovery of vitamins in the early $20^{\text {th }}$ century (Dowling 2012). As a postdoctoral fellow in Germany, Wald had shown that visual pigments consist of vitamin A aldehyde, now called retinal, bound to a protein called opsin, the light sensitive molecule in photoreceptors. The question then was, how does vitamin A get converted to retinal? This was the project investigated by Ruth Hubbard for her Ph.D. (Hubbard 1950). She found that the next question was how can one make a visual pigment molecule from retinal and opsin? With other members of the Wald lab, Hubbard showed that to synthesize a visual pigment molecule, the retinal needed to be in a specific shape, a so-called cisisomer. The retinal would then spontaneously bind to opsin to form a visual pigment molecule identical to the native molecule (Dowling 2012). After completing her Ph.D. in 1950, Hubbard continued as a research fellow in Wald's lab at Harvard, carrying on her work on vision. She held a Guggenheim Fellowship at Carlsberg Laboratory in Copenhagen, Denmark from 1952 to 1953 and then returned to Harvard. In a third 
important piece of research in the mid-1950s she and a postdoctoral fellow in the Wald lab, Allen Kropf, showed that the role of light in the visual process is limited to changing the shape of retinal (isomerizing it). This allows opsin to change its shape, and leading to excitation of the photoreceptors (Hubbard and Kropf 1958). Their work led to an understanding of how light actually initiates vision. For this and her other seminal contributions, Hubbard was later elected a member of the American Association for the Advancement of Science (AAAS) and, with Wald, was awarded the prestigious Paul Karrer Medal in 1967.

Allen Kropf later described Hubbard as an exacting mentor: "She was an intellectually demanding critic but an enthusiastic supporter of my fumbling efforts to learn" (In celebration of Ruth Hubbard: Her life and work 1990, p. 6).

\section{Family Life}

One summer in the late 1940s when they were both working at the Marine Biological Laboratory in Woods Hole, Massachusetts, Wald and Hubbard had fallen in love, even though both were married to other people and Wald was more than 17 years older than she (Corbett 2016). They kept the affair secret for years. After their respective marriages broke down, they finally married in 1958. They had two children, Elijah, born in 1959, now a Grammy Award-winning Folk blues guitarist and music historian, and Deborah, born in 1961, now an attorney. The Walds remained devoted to each other and to their work for the rest of their lives.

\section{Changing Interests: From Scientist to Activist}

Ruth Hubbard held a number of positions while she was in the Wald lab, but although she loved her research, by the late 1960s, her interests had begun to shift from science to social activism. She actively protested against the Vietnam War and started taking her children to 
antiwar demonstrations. She noticed how science was contributing to the war, not just through developing weapons but also by the use of chemicals such as defoliants (Corbett 2016). Around the same time, she was asked to speak at an AAAS meeting in Chicago about being a female scientist. In talking with other women in preparation for the presentation, she found that there were many similarities in their experiences. She later remarked that until that moment, although all of them were highly accomplished and recognized for their research, none of them had what she called "real jobs" (Holloway 1995, p. 50). She referred to the kinds of positions women typically held at the time - as assistants or lecturers - as "nonjobs" (Corbett 2016, para. 6). She noted in 1981 that the realization that they all had marginal jobs "was an amazing experience ... to kind of confront the level of discrimination that was, in fact, out there" (Walzer 1981, p. 107).

Early in her career, Hubbard had never questioned the position of women in science. Gradually, however, as her interest and involvement with feminism grew, she began to question long-held assumptions. As one writer puts it, "she was grateful to be a female biologist - until she got mad about needing to be grateful" (Corbett 2016, subtitle). She felt the university, by allowing her to do research, was "doing [her] a favor, like so many women at the time" (Walzer 1981, p. 114). Then in 1974, the Chair of Biology and several colleagues recommended Hubbard for a faculty position based on her considerable research accomplishments. She was appointed Professor of Biology and so became the first woman tenured in the Biology Department at Harvard. Her previously somewhat tenuous position at Harvard then became stable. She described it "as a real opening up and increase in freedom and options" (Walzer 1981, p. 114). In 1975, Hubbard established a course called "Biology and Women's Issues" (Biology 
109), a first at Harvard. It began as a small seminar at Radcliffe (regular classes were still being held there at the time; today it is the Radcliffe Institute for Advanced Study and classes are all held at Harvard College), but by 1979 it had over 80 students. Even today, courses are taught that build on Bio 109's approach, taking a critical look at biology and science in relation to women's health, gender and sexuality. Hubbard's daughter, Deborah Wald, said that her mother "truly was a mentor to a generation of progressives, feminists, and LGBT students at Harvard, and that meant a lot to her" (Gillinov 2016, p. 17).

Around 1976, Hubbard stopped working in the lab. John Dowling, a colleague and the Gordon and Llura Gund Research Professor of Neuroscience at Harvard, remarks that "she did marvelous science and many of her colleagues were disappointed that she gave up science" (Dowling, personal communication, August 10, 2017). Some of her expressed views at that time, especially her rejection of sociobiology and recombinant DNA research, upset certain of her colleagues, though others were supportive. Stephen Jay Gould, a colleague for 20 years, on the occasion of her retirement in 1990 described her as "a beacon and a support for radical and feminist perspectives - a focus and a gadfly for a view of life that needs constant defending and nurturing" (In celebration of Ruth Hubbard: Her life and work,1990, p. 2). Geneticist and evolutionary biologist Richard Lewontin described her as "a tireless and influential critic of the biological theory of women's inequality" (Lewontin 1994, para. 18).

During the early years of the Walds' marriage, there was ongoing debate about whether women were able to manage both a career and children. Hubbard commented that she had grown up in Austria, where many women in her class were expected to have professional lives and "entrust the care of their children to other women. So [she] did not have any major emotional barriers to 
cross " about having a full professional life as a mother (Holloway 1995, p. 50). In this too she was ahead of her time.

In the mid-1990s Hubbard became interested in what she termed genomania - "oversimplifying science and assigning every trait, including behaviors, a genetic cause" (Holloway 1995, p. 50). She called this "the myth of the all-powerful gene" (Hubbard and Wald, 1993). She was concerned that this concentration on identifying genes would ultimately involve ethical decisions for which society was not prepared. She feared that insurers might deny coverage to people who were identified as having defective genes, but also that doctors would custom make embryos so-called designer children. This is an especially topical issue today because of the work done by researchers in Oregon to eliminate a life-threatening defective gene in a mouse embryo (Ma et al. 2017).

Hubbard was also concerned that linking a particular gene to a disease would overlook all of the complicated biological interactions involved. And indeed, just 22 years later, scientists are in fact continually discovering how very complicated indeed those processes are. Also, as a Jew who fled Austria in the late 1930s with her family, Hubbard was especially worried about eugenics. In 1993, she co-wrote with her son Elijah the book Exploding the Gene Myth. In the preface, they say "Are living organisms machines, so that it is safe to replace a gear here and a cog there, or are we too complex for anyone to foresee the effects of genetic tinkering?" (Hubbard and Wald 1993, p. xiv).

\section{Later Years}

When George Wald died in 1997, Hubbard was devastated. Her son recalls that since Wald had been ill for two years and she had been caring for him, when he died she expected that she "would get on with her life - but with him gone, she kind of lost interest. It was the last thing she 
had expected, as an active feminist, but he had been such a central part of her life" (Wald, personal communication, August 1, 2017). She became less publicly active but continued working for social justice groups. She also took up poetry and painting and continued taking long walks around Cambridge in the winters and Woods Hole in the summers, swimming in the ocean off Woods Hole as long as she was able. She died peacefully at home in Cambridge on September 1, 2016, with son Elijah and daughter Deborah at her side. A memorial service was held on March 7, 2017.

\section{Conclusion}

Ruth Hubbard's work on vision was groundbreaking. To date, according to the Web of Science, her articles have been cited 3,534 times (an average of 49.7 times per year). Here is a sample:

- Tautomeric forms of metarhodopsin (with R. G. Matthews, P. K. Brown and G. Wald). 1963. The Journal of General Physiology 47: 215-240. Cited 499 times to date.

- Cis-trans isomers of vitamin A and retinene in the rhodopsin system (with G. Wald). 1952. The Journal of General Physiology 36(2): 269-315. Cited 380 times to date.

- The action of light on rhodopsin (with A. Kropf). 1958. Proceedings of the National Academy of Sciences of the United States of America 44(2): 130-139. Cited 300 times to date.

- The rhodopsin system of the squid. 1958. The Journal of General Physiology 41(3): 501528. Cited 220 times to date.

- The chemistry of visual photoreception (with D. Bownds and T. Yoshizawa). 1965. Cold Spring Harbor Symposia on Quantitative Biology 30: 301-315. Cited 146 times to date. Hubbard published in all the journals considered important during her time including Nature, Science, and more. There were over 50 publications in her curriculum vitae when she was 
offered tenure, and her papers are still being cited today. "Ruth Hubbard was a superb scientist who contributed substantially to our understanding of photoreceptors" (Dowling 2016). Outside the scientific community, Ruth Hubbard Wald is well known for her social activism. In fact, it ran in the family; both of her parents had been activists in Austria, and Ruth's younger brother Alexander Hoffmann was a liberal lawyer who worked with Cesar Chavez and members of the Black Panther Party (Marquard 2016).

Hubbard was a mentor and inspiration to many female scientists over the years. Nancy Krieger, a former student and now a Professor of Epidemiology at the Harvard Chan School of Public Health, said that Hubbard taught her "both to think critically about science and also to do science critically, and always to challenge whenever biology was used for an excuse for injustice" (Gillinov 2016, para. 8).

Evelyn Fox Keller, then at the University of California at Berkeley, said at the Symposium in Hubbard's honor in 1990 that "Ruth's confidence that women could and should be scientists shone like a beacon; but even more to the point she showed us how to do it, she exemplified the possible in impossible times" (In celebration of Ruth Hubbard: Her life and work 1990, p. 4). Hubbard dedicated her 1979 book Women Look at Biology Looking at Women to "the many women, past and present, who have constricted their aspirations to fit within what they were told" (Hubbard, Henifrin, and Fried 1979).

Hubbard's groundbreaking work on vision rightfully earned her appointment as the first woman tenured in the Biology Department at Harvard. Her social criticism of science was broad and still resonates today. She stated that not only women but also nonwhite and lower income men have been in many ways excluded from what she called "the process of science-making" (Marquard 2016, para. 4). Rather, she felt that science has been the province of "Caucasian, highly educated 
and economically privileged men (Hubbard 1986, p. 4). And indeed, science reflects the values and ideas of the society in which it takes place; it doesn't occur in a vacuum. Even today, women are underrepresented in some fields of science, as are minorities and poorer people.

Ruth Hubbard encouraged many women scientists through her teaching and mentoring as well as by her example. John Dowling (personal communication, August 10, 2017) has said that she should "be remembered as someone who contributed much to both science and to the role of women in science and society."

\section{References}

"In Celebration of Ruth Hubbard: Her Life and Work." 2017. https://mcbpublic.unix.fas.harvard.edu/mcb_files/media/editor_uploads/2016/10/ruth hu bbard symposium.pdf.

Benderly, Beryl Lieff. 2016. "Ruth Hubbard and the evolution of biology." Science. http://www.sciencemag.org/careers/2016/10/ruth-hubbard-andevolution-biology.

Corbett, Sara. 2016, December 11. "Ruth Hubbard challenged the male model of science." The New York Times Magazine. Retrieved from:

https://www.nytimes.com/interactive/2016/12/21/magazine/the-lives-they-lived-ruthhubbard.html.

Dowling, John E. 2012. The Retina: An Approachable Part of the Brain. Rev. ed. Cambridge MA: Belknap Press of Harvard University Press.

Dowling, John. 2016. "Re Ruth Hubbard." Email to committee organizing Celebration of the Life and Work of Ruth Hubbard Wald, held March 26, 2017.

Drexler, Madeline. 1990, May 16. "Ruth Hubbard, an outsider inside." Boston Globe, May 16. Retrieved from: https://search.proquest.com/docview/403323828. 
Gillinov, Stephen M. 2016, September 8. "Ruth Hubbard, Harvard Biology Professor and political activist, dies at 92." The Harvard Crimson. Retrieved from http://www.thecrimson.com/article/2016/9/8/Ruth-Hubbard-passes/.

Griffin, Donald R., Ruth Hubbard, and George Wald. 1947. "The sensitivity of the human eye to infra-red radiation." Journal of the Optical Society of America 37 (7): 546-553.

Holloway, Marguerite. 1995. "Turning the inside out." Scientific American 272 (6): 49- 50.

Hubbard, Ruth. 1950. The Interconversion of Retinene and Vitamin A. with a Note on the Synthesis of Rhodopsin. (Unpublished doctoral dissertation). Radcliffe College, Cambridge MA.

Hubbard, Ruth. 1986. Reflections on my life as a scientist. The Radical Teacher 30: 3-7.

Hubbard, Ruth, Barbara Fried, and Mary Sue Henifin. 1982. Biological Woman—the Convenient Myth: A Collection of Feminist Essays and a Comprehensive Bibliography. Cambridge MA: Schenkman Pub. Co.

Hubbard, Ruth and Allen Kropf. 1958. "The action of light on rhodopsin." Proceedings of the National Academy of Sciences of the United States of America 44(2): 130-139.

Hubbard, Ruth, \& Wald, Elijah. (1993). Exploding the gene myth: How genetic information is produced and manipulated by scientists, physicians, employers, insurance companies, educators, and law enforcers. Boston: Beacon Press.

Lewontin, Richard C. 1994, April 7. "Women versus the biologists - Exploding the Gene Myth by Ruth Hubbard and Elijah Wald." The New York Review of Books. Retrieved from http://www.nybooks.com/articles/1994/04/07/women-versus-the-biologists/.

Ma, H., Marti-Gutierrez, N., et al. (2017). Correction of a pathogenic gene mutation in human embryos. Nature 543:413-419. 
Marquard, B. 2016, September 4. "Ruth Hubbard, 92, first woman tenured in biology at Harvard.” BostonGlobe.com. Retrieved from https://www.bostonglobe.com/metro/2016/09/04/ruth-hubbard-first-womantenured-biology-harvard/zdiRSECiShE4rAJaCBNNTP/story.html

Walzer, Judith 1981. Oral history of tenured women in the Faculty of Arts and Sciences at Harvard University. Unpublished manuscript. Schlesinger Library, Harvard University, Cambridge MA. 